\title{
Association of vitamin D and osteocalcin levels in post-menopausal women with osteoporosis
}

\author{
Yogiraj Vaijanathrao Chidre ${ }^{1 *}$, Amir Babansab Shaikh²
}

\begin{abstract}
${ }^{1}$ Department of Obstetrics and Gynecology, Mallareddy Medical College for Women, Hyderabad, India
${ }^{2}$ Department of Obstetrics and Gynecology, Government Medical College, Latur, Maharashtra, India
\end{abstract}

Received: 12 February 2017

Accepted: 18 February 2017

\section{*Correspondence: \\ Dr. Yogiraj Vaijanathrao Chidre, \\ E-mail: cpmreddy@gmail.com}

Copyright: ( $)$ the author(s), publisher and licensee Medip Academy. This is an open-access article distributed under the terms of the Creative Commons Attribution Non-Commercial License, which permits unrestricted non-commercial use, distribution, and reproduction in any medium, provided the original work is properly cited.

\section{ABSTRACT}

Background: Osteoporosis is a common age related problem especially in women, with a consequent increase in bone fragility and susceptibility to fracture. Apart from Calcium, another nutrient that plays an important role in the mineralization of skeleton in Vitamin D. Osteocalcin, which is produced primarily by osteoblasts during bone formation, is considered to be one of the markers for osteoporosis.

Methods: 314 women above the age of 40 were included into the study. A thorough physical and clinical examination, assessment of vital parameters, anthropometry evaluation was done for all patients. Bone mineral density was calculated using central DXA osteodensitometer at lumbar spine L1-L4, hip and ultradistal radius (in some cases.). Blood samples were taken for the detection of ionized calcium, phosphorus, alkaline phosphatase, 25hydroxivitamin D (25 ODH) and serum parathyroid hormone (PTH) by chemiluminiscent assay. Bone markers such as osteocalcin were measured as required.

Results: Out of the 314 women attending our OPD, 96 of them were diagnosed as having osteoporosis. 24 out of them had fragility fractures, mainly of the hip, and 82 had ostepenia. Elevated levels of calcium $(8.96 \mathrm{mg} / \mathrm{dl})$, parathyroid hormone $(58.76 \mathrm{pg} / \mathrm{ml})$ and osteocalcin $(24.46 \mathrm{ng} / \mathrm{ml})$ were observed. Vitamin D deficiency of $\leq 20$ was seen in $59(63 \%)$ of the cases, insufficient in $23(24 \%)$ and only $12(13 \%)$ of these women had normal Vitamin D levels.

Conclusions: Osteocalcin is a promising marker for the detection of osteoporosis. There is a considerable Vitamin D deficiency among the women with osteoporosis, and it is under-treated. It is essential to provide Vitamin D supplementation to these women especially those who are at high risk for fragility fractures.

Keywords: Osteocalcin, Osteoporosis, Post-menopause, Viamin D deficiency

\section{INTRODUCTION}

Osteoporosis is has a very great impact on most of the post-menopausal women. It is defined as a progressive systemic skeletal disorder characterized by low bone mass and micro-architectural deterioration of bone tissue, with a consequent increase in bone fragility and susceptibility to fracture. ${ }^{1}$ It is a common age related problem especially in women. Fragility fractures due to osteoporosis is the most disabling consequence which result in loss of normal function of the person, serious morbidity and associated three-fold increase in mortality, not to mention a high socio-economic burden. ${ }^{2}$

According to the World Health organization, osteoporosis is second only to cardiovascular disease as a leading health problem throughout the world. The incidence of women having fractures due to osteoporosis worldwide is 
$30-40 \% .^{3}$ In India, osteoporosis occurs 10 years earlier than the west. It affects one in three women and one in five men over the age of $50 .{ }^{4}$ Soon after menopause there is a marked increase in the bone turnover. ${ }^{5,6}$ This is probably due to a decrease in the estrogen levels that act directly on bone cells. ${ }^{7}$

In addition, the estrogen deficiency may indirectly act on extraskeletal calcium homeostasis and induce a further loss in calcium. ${ }^{8}$ Nutrition is one of the major factors responsible for the pathogenesis, prevention and the treatment of osteoporosis. Apart from Calcium, another nutrient that plays an important role in the mineralization of skeleton in Vitamin D.

Vitamin D is derived from the exposure to the sunlight, food and other dietary supplements. Still, insufficiency persists in many parts of the world due to nutritional deficit and avoidance of the sunlight and the use of sunscreens. ${ }^{9}$ Limited outdoor activity, lower dietary intake and reduced capacity of the skin to produce Vitamin D may the possible reasons for the deficiency of this nutrient in the elderly. ${ }^{10}$ This leads to secondary hyperparathyroidism which further enhances bone remodeling and results in cortical bone loss. ${ }^{11}$ There are several markers for the detection of done formation and resorption such as procollagen I N-terminal extension peptide and $\mathrm{C}$-telopeptide breakdown products. Another bone-specific protein is osteocalcin which is produced primarily by osteoblasts during bone formation. ${ }^{12}$ It is the major and most thoroughly characterised noncollagenous protein in mature human bone, where it constitutes $1-2 \%$ of the total protein. ${ }^{13}$

This present study was hence undertaken to evaluate the prevalence of osteoporosis in women above the age of 40 years in our surrounding area, and their association with Vitamin D deficiency. Osteocalcin as one of the markers was also considered in the study.

\section{METHODS}

This study was conducted at Department of Obstetrics and Gynecology, Mallareddy Medical College for Women. 314 women above the age of 40 who attended our outpatient ward for the period of 1 year, were included into the study. All the women were menopausal for more than 1 year with a decreased bone density of $\mathrm{T}$ score-1.0 or less (in the lumbar spine or right or left femoral neck).

The patients who were already on estrogen therapy within 1 year of diagnosis, or abnormal renal function i.i with serum creatinine levels $>1.5 \mathrm{mg} \%$ or with renal calculi were excluded from the study. Patients with renal, live or esophageal diseases which require medications, abnormal thyroid function, patients on steroids were also excluded from the study. The study was thoroughly explained to the patients and informed consent was taken form all of them. Demographic details of the patients were noted, and they were subjected to a thorough physical and clinical examination, assessment of vital parameters, anthropometry evaluation. Bone mineral density was calculated using central DXA osteodensitometer at lumbar spine L1-L4, hip and ultradistal radius (in some cases).

$\mathrm{T}$ scores were calculated with Normal value being value of $\mathrm{BMD} \pm \mathrm{SD}$ of the young adult reference value, low bone mass (osteopenia) between BMD >1 SD and <2.5 $\mathrm{SD}$ lower than the young adult reference mean, Osteoporosis with BMD more 2.5 SD lower than the reference values. Severe osteoporosis was categorized as BMD 2.5 SD lower than the reference values and with fragility fractures.

Blood samples were taken for the detection of ionized calcium, phosphorus, alkaline phosphatase, 25 hydroxivitamin D (25 ODH) and serum parathyroid hormone (PTH) by chemi-luminiscent assay. Bone markers such as $\beta$ crosslaps and osteocalcin were measured as required. Vitamin D sufficiency is defined as a serum 25 OHD value between $30-100 \mathrm{ng} / \mathrm{ml}$, insufficiency between $21-29 \mathrm{ng} / \mathrm{ml}$ and values $<20$ were considered as Vit D deficiency.

\section{RESULTS}

Out of the 314 women attending our OPD, 96 of them were diagnosed as having osteoporosis. 24 out of them had fragility fractures, mainly of the hip, and 82 had osteopenia. The rest were normal (Figure1).

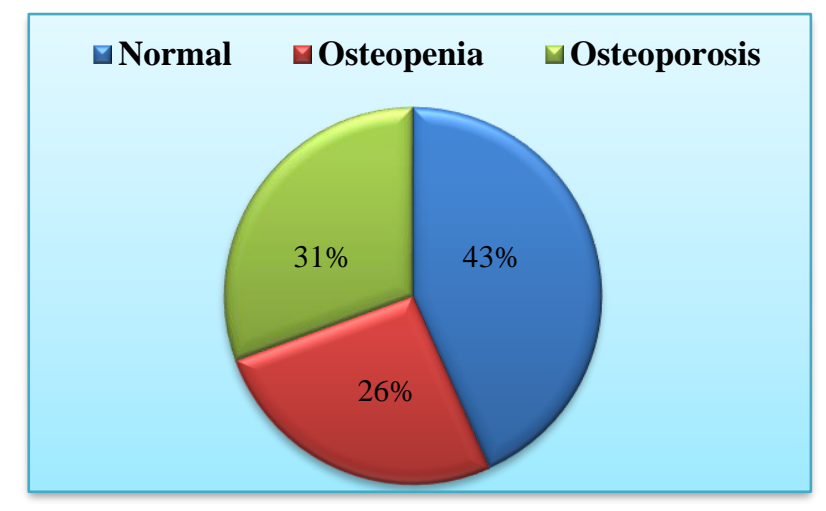

Figure 1: Bone density of the patients.

The mean age of the study group was 58.3 years. The approximate duration of menopause among the women with osteoporosis was 9.4 years. BMI of the patients was calculated based on their weight and height and was found to be 26.2 .

The $\mathrm{T}$ score in the lumbar spine was -3.25 and in the hip it was -1.91 . Elevated levels of calcium $(8.96 \mathrm{mg} / \mathrm{dl})$, parathyroid hormone $(58.76 \mathrm{pg} / \mathrm{ml})$ and osteocalcin (24.46 ng/ml) was observed. 
Table 1: General parameters in postmenopausal women with osteoporosis.

\begin{tabular}{|l|l|}
\hline Parameters & $\begin{array}{l}\text { postmenopausal } \\
\text { women with } \\
\text { osteoporosis } \\
\text { n=96 }\end{array}$ \\
\hline Age ( in years) & $58.3 \pm 6.3$ \\
\hline Duration of menopause & $9.4 \pm 7.2$ \\
\hline BMI $\left(\mathrm{kg} / \mathrm{m}^{2}\right)$ & $26.2 \pm 3.8$ \\
\hline BMD hip $\left(\mathrm{g} / \mathrm{cm}^{2}\right)$ & $0.79 \pm 0.2$ \\
\hline BMD lumbar vertebra $\left(\mathrm{g} / \mathrm{cm}^{2}\right)$ & $0.78 \pm 0.3$ \\
\hline T score hip & $-1.92 \pm 1.07$ \\
\hline T score lumbar vertebra & $2.97 \pm 1.19$ \\
\hline Calcium levels $(\mathrm{mg} / \mathrm{dl})$ & $8.96 \pm 3.1$ \\
\hline Ionized Ca $(\mathrm{mg} / \mathrm{dl})$ & $4.26 \pm 1.1$ \\
\hline ALP $(\mathrm{IU} / \mathrm{L})$ & $69.26 \pm 7.25$ \\
\hline P $(\mathrm{mg} / \mathrm{dl})$ & $3.21 \pm 0.93$ \\
\hline PTH $(\mathrm{pg} / \mathrm{mL})$ & $58.76 \pm 8.1$ \\
\hline Serum creatinine $(\mathrm{mg} / \mathrm{dl})$ & $10.1 \pm 0.13$ \\
\hline Serum TSH $(\mathrm{mIU} / \mathrm{L})$ & $2.91 \pm 1.1$ \\
\hline 25 OHD $(\mathrm{ng} / \mathrm{ml})$ & $18.67 \pm 3.9$ \\
\hline Deficiency & $12.92 \pm 2.19$ \\
\hline Insuffecient & $24.23 \pm 4.31$ \\
\hline Normal & $36.42 \pm 2.98$ \\
\hline Osteocalcin $(\mathrm{ng} / \mathrm{ml})$ & $24.46 \pm 4.7$ \\
\hline Betacrosslaps $(\mathrm{ng} / \mathrm{ml})$ & $0.6 \pm 0.1$ \\
\hline
\end{tabular}

Among the patients with osteoporosis, vitamin D deficiency of $\leq 20$ was seen in $59(63 \%)$ of the cases, insufficient in $23(24 \%)$ and only $12(13 \%)$ of these women had normal Vitamin D levels (Figure 2).

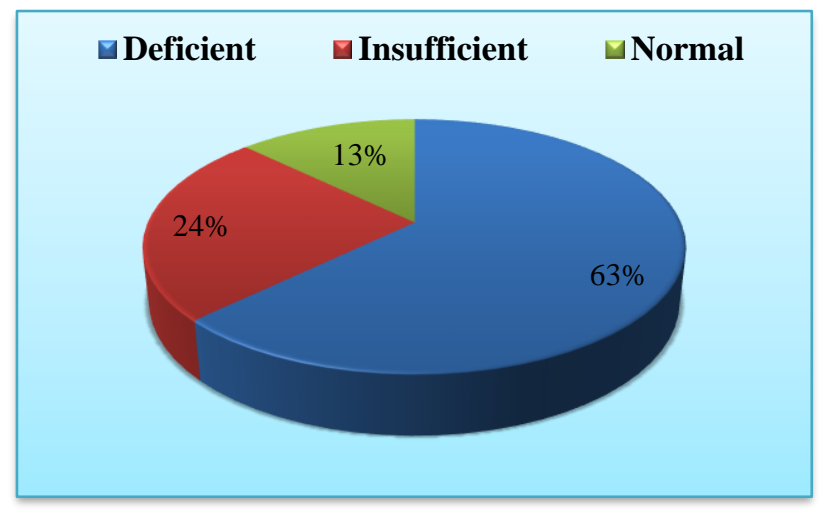

Figure 2: Prevalence of Vitamin D deficiency among the patients with osteoporosis.

\section{DISCUSSION}

Menopause results in a reduction in skeletal mass caused by imbalance between bone reabsorption and bone formation due to loss in ovarian function. Hence the loss in ovarian functions is said to be the most important factor in the development of post-menopausal osteoporosis. Vitamin D insufficiency has been shown to have adverse effects on calcium metabolism, osteoblastic activity, matrix ossification, bone mineral density and bone remodeling. Low serum 25 hydroxy vitamin D concentration is associated with secondary hyperparathyroidism, increased bone turnover, reduced BMD and elevated risk of osteoporotic fractures. ${ }^{14,15}$

In present study, we found an incidence of 30.6\% (96/314 patients) to have osteoporosis, $26.1 \%$ (82/314) had osteopenia and the rest of the patients were normal. $19.5 \%$ had osteopororsis in another study by Capatina et al, and $49.3 \%$ of incidence was reported by Beg et al. ${ }^{15,16}$ Similar were the results in other studies also.,17,18 The mean age of the post-menopausal women was 58.3 years which was consistent with many other studies ${ }^{15,16}$. The BMI was less than 30 in most of the cases and was not considered to be a risk factor for osteoporosis. No significant association of BMI and osteoporosis was observed by Al- Daghri et al and De Laet et al, although other researchers such as Reid et al found osteoporosis to be more common among women with low BMI. ${ }^{19-21}$

Vitamin D deficiency, throughout the world is considered a serious condition which has significant consequences in the individual, not only with bone and musculoskeletal health but results in a wide range of chronic diseases. ${ }^{10,22}$ We have reported a $63 \%$ Deficiency and $24 \%$ insufficiency of $25 \mathrm{OHD}$ among the women with osteoporosis. This was consistent with other studies who also reported a high prevalence of Vitamin D Deficiency with low 25 OHD levels. Higher levels of secondary parathyroid hormone were also found in these patients. This was found to increase with age, and was more likely due to the deterioration of renal function and decrease in 25 OHD levels. This relationship of decreased 25 OHD and PTH levels were observed in other studies also. ${ }^{23-26}$

Osteocalcin is synthesized in the skeleton by osteoblasts, the cells responsible for the bone formation. It is said to be one of the important marker for bone formation. It has a high affinity to calcium and a compact calcium dependent $\alpha$ helical conformation, in which the $\gamma$ carboxyglutamic acid (Gla) residues binds and promote absorption to hydroxyapatite in bone matrix. This is how bone minealization takes place.

The deficiency in calcium and phosphorous may lead to lowering of formation of hydroxyapatite crystals in osteopootic women. This as the bone mineralization is reduced, fee osteocalcin may be observed in the blood which explains its high concerntration in the serum of post-menopausal women, thereby making it one of the important markers of osteoporosis. ${ }^{3,27} \mathrm{We}$ reported a high osteocalcin levels in our study which was corroborated by similar studies by Jagtap et al, Verit et al, Cabrera et al and Rosenquist et al. ${ }^{3,28-30}$ A therapy of 3 months of a combination of alendronate + calcium + Vitamin D was suggested to prevent the bone loss, preserving bone architecture and increasing the bone strength by suppressing the bone turnover. ${ }^{2,3}$ 


\section{CONCLUSION}

Present study thus conclude that Osteocalcin is a promising marker for the detection of osteoporosis. There is a considerable Vitamin D deficiency among the women with osteoporosis, and it is under treated. It is essential to provide Vitamin d supplementation to these women especially those who are at high risk for fragility fractures. Proper clinical advice and counseling is essential for compliance of the medication so as to prevent greater morbidity and eventual mortality.

\section{Funding: No funding sources}

Conflict of interest: None declared

Ethical approval: The study was approved by the Institutional Ethics Committee

\section{REFERENCES}

1. Axelrod DW, Teitelbaum SL. Results of long-term cyclical etidronate therapy: bone histomorphometry and clinical correlates. J Bone Miner Res. 1994;9S1:136.

2. Sambrook P and Cooper C. Osteoporosis. Lancet 2006;367:2010-8.

3. Jagtap VR, Ganu JV, Nagane NS. BMD and serum intact osteocalcin in post-menopausal osteoporosis women. Indian J Clin Biochem; 2011;26:70-3.

4. Moyad MA. Preventing male osteoporosis: prevalence, risks, diagnosis and imaging tests. Urol Clin N Am. 2004;31:321-30.

5. Heaney RP, Recker RR, Saville PD. Menopausal changes in bone remodeling. J Lab Clin Med. 1978;92:964-70.

6. Uebelhart D, Schlemmer A, Johansen JS, Gineyts E, Christiansen C, Delmas PD. Effect of menopause and hormone replacement therapy on the urinary excretion of pyridinium cross-links. J Clin Endocrinol Metab. 1991;72:367-73.

7. Manolagas SC, Jilka RL. Bone marrow, cytokines, and bone remodeling: emerging insights into the pathophysiology of osteoporosis. N Engl J Med. 1995;332:305-311.

8. Gennari C, Agnusdei D, Nardi P, Civitelli R. 1990 Estrogen preserves a normal intestinal responsiveness to 1,25-dihydroxyvitamin D3 in oophorectomized women. J Clin Endocrinol Metab. 71:1288-1293.

9. Zittermann A. Vitamin D in preventive medicine: are we ignoring the evidence? Br J Nutr. 2003;89:55272.

10. Holick MF. Vitamin D deficiency. N Engl J Med. 2007;357:266-81.

11. Ridker PM, Buring JE, Cook NR, Rifai N. C-reactive protein, the metabolic syndrome, and risk of incident cardiovascularn events: an 8-year follow-up of 14719 initially healthy American women. Circulation. 2003;107:391-7.

12. Vasikaran S, Eastell R, Bruyere O, Foldes AJ, Garnero P, Griesmacher A, McClung M, Morris HA,
Silverman S, Trenti T, Wahl DA, Cooper C, Kanis JA. Markers of bone turnover for the prediction of fracture risk and monitoring of osteoporosis treatment: a need for international reference standards. Osteoporos Int. 2011,22:391-420.

13. Price PA, Parthemore JG, Deftos LJ. New biochemical marker for bone metabolism. Measurement by radioimmunoassay of bone GLA protein in the plasma of normal subjects and patients with bone disease. J Clin Invest. 1980;66:878-83.

14. Lukert B, Higgins J, Stoskopf M. Menopausal bone loss is partially regulated by dietary intake of vitamin D. Calcif Tissue Int. 1992;51:173-9.

15. Beg M, Akhtar N, Alam MF, Rizvi I, Ahmad J, Gupta A. Vitamin D status and serum osteocalcin levels in post-menopausal osteoporosis: Effect of bisphosphonate therapy. JIACM. 2014;15(3-4):172-6.

16. Capatina $\mathrm{C}$, Carsote $\mathrm{M}$ Caagheorgheopol A, poiana C, Berteanu M. Vitamin D deficiency in postmenopausal women-biological correlates. Maedica (Buchar). 2014;9(4):316-22.

17. Neetakumar, Ammini AC, Tandon N, Goswami R, Dineshkumar, Singh A. Ethnic variation of host and risk factors in silent epidemic of osteoporosis. Orthoped Today. 2004;VI(4):240-4.

18. Johannes WG, Pet PMM, Ron NJ, Lems WF, Roland FJ, Ann MH, Ale A, Erik B, Lorenz CH, George AWB, Ben ACD. Prevention of glucocorticoid induced osteoporosis with alendronate or alfa calcidiol: relations of change in bone mineral density, bone markers and calcium homeostasis. J Rheumatol. 2007;34:1051-7.

19. Nasser M Al-Daghri, Sobhy Yakout, Eman AlShehri, Hanan A Al-Fawaz, Naji Aljohani, Yousef Al-Saleh. Inflammatory and bone turnover markers in relation to PTH and vitamin D status among saudi postmenopausal women with and without osteoporosis. Int J Clin Exp Med. 2014;7(10):3528-35.

20. De Laet C, Kanis JA, Oden A, Johanson H, Johnell O, Delmas P, Eisman JA, Kroger H, Fuji-wara S, Garnero P, McCloskey EV, Mellstrom D, Melton LJ 3rd, Meunier PJ, Pols HA, Reeve J, Silman A and Tenenhouse A. Body mass index as a predictor of fracture risk: a meta-analysis. Osteoporos Int. 2005;16:1330-8.

21. Reid IR. Relationships among body mass, its components, and bone. Bone. 2002;31:547-55.

22. Holick MF, Chen TC. Vitamin D deficiency: a worldwide problem with health consequences. Am J Clin Nutr. 2008;87:1080S-6S.

23. Lips, P, Duong, T, Oleksik, A, Black D, Cummings S, Cox D et al. A global study of vitamin D status and parathyroid function in postmenopausal women with osteoporosis: Baseline data from the multiple outcomes of raloxifene evaluation clinical trial. J Clin Endocrinol Metab. 2001;86:1212-21.

24. Harris SS, Soteriades E, Dawson-Hughes B. Secondary hyperparathyroidism and bone turnover in 
elderly blacks and whites. J Clin Endocrinol Metab. 2001;86:3801-4.

25. Ghazali A, Fardellone P, Pruna A, Atik A, Achard JM, Oprisiu R et al. Is low plasma 25-(OH) vitamin $\mathrm{D}$ a major risk factor for hyperparathyroidism and Looser's zones independent of calcitriol? Kidney Int. 1999;55:2169-77.

26. Gómez-Alonso C1, Naves-Díaz ML, FernándezMartín JL, Díaz-López JB, Fernández-Coto MT, Cannata-Andía JB. Vitamin D status and secondary hyperparathyroidism: the importance of 25hydroxyvitamin D cut-off levels. Kidney Int Suppl. 2003;(85):S44-8.

27. Pino JD, Gomez EM, Rodriguez MM, Sosa CL, Cordero M, Lanchares JL, Talavera JRG. Influence of sex, age and menopause in serum osteocalcin (BGP) levels. J Mol Med. 1991;69(24):1135-8.
28. Verit FF, Yazgan P, Geyikli C, Zer Y, Celik A. Diagnostic value of TRAP $5 b$ activity in postmenopausal osteoporosis. J Turkish-German Gynecol Assoc. 2006;7(2):120-4.

29. Cabrera CD, Henriquez MS, Traba ML, Villafane EA, Piedra DL. Biochemical markers of bone formation in the study of postmenopausal osteoporosis. Osteoporos Int. 1998;8(2):147-51.

30. Rosenquist C, Qvist P, Bjarnason N, Christiansen C. Measurement of a more stable region of osteocalcin in serum by ELISA with two monoclonal antibodies. Clin Chem. 1995;41(10):1439-45.

Cite this article as: Chidre YV, Shaikh AB.

Association of vitamin $\mathrm{d}$ and osteocalcin levels in post-menopausal women with osteoporosis. Int J Reprod Contracept Obstet Gynecol 2017;6:1244-8. 